\title{
Monosynaptic Circuit Tracing with Glycoprotein-Deleted Rabies Viruses
}

\author{
타w $\mathrm{Edward}$ M. Callaway ${ }^{1}$ and Liqun Luo ${ }^{2}$ \\ ${ }^{1}$ Systems Neurobiology Labs, The Salk Institute for Biological Studies, La Jolla, California 92037, and 2Department of Biology and Howard Hughes Medical \\ Institute, Stanford University, Stanford, California 94305
}

\begin{abstract}
Introduction
Since the introduction of methods using glycoprotein $(\mathrm{G})$-deleted rabies virus (RVdG) to identify the direct monosynaptic inputs to genetically targeted neurons eight years ago (Wickersham et al., 2007b), this approach has been widely used for sophisticated circuit-tracing studies throughout the central and peripheral nervous systems. Published studies using monosynaptic RV tracing have described the connections to single neurons (Marshel et al., 2010; Rancz et al., 2011; Vélez-Fort et al., 2014), to cell types defined by their projection to particular locations (Stepien et al., 2010; Yonehara et al., 2011; Takatoh et al., 2013; Cruz-Martín et al., 2014; Levine et al., 2014; $\mathrm{Ni}$ et al., 2014; Sreenivasan et al., 2015), to cells targeted by their birth date (Arenkiel et al., 2011; Nakashiba et al., 2012; Vivar et al., 2012; Deshpande et al., 2013; Li et al., 2013; Garcia et al., 2014), to neurons with particular cell-surface receptors (Choi and Callaway, 2011), and to genetically identified cell types in Cre- or tTA-expressing
\end{abstract}

Received Jan. 29, 2015; revised April 28, 2015; accepted May 12, 2015.

The work in the laboratory of E.M.C. is funded by the National Institutes of Health (NIH; EY02577 and MH063912) the Howard Hughes Medical Institute (HHMI), and the Gatsby Charitable Foundation. Work in the laboratory of L.L. is funded by HHMI and the NIH (NS050835). We thank former and present members of our labs for their contributions to the development of the methods described here.

The authors declare no competing financial interests.

Correspondence should be addressed to Edward M. Callaway, Systems

Neurobiology Labs, The Salk Institute for Biological Studies, 10010 North Torrey Pines Road, La Jolla, CA 92037. E-mail: callaway@salk.edu.

DOI:10.1523/JNEUROSCI.0409-15.2015

Copyright $\odot 2015$ the authors $\quad 0270-6474 / 15 / 358979-07 \$ 15.00 / 0$ mouse lines (Haubensak et al., 2010; Wall et al., 2010; Weible et al., 2010; Miyamichi et al., 2011; Watabe-Uchida et al., 2012; Wall et al., 2013; Fu et al., 2014; Kohara et al., 2014; Ogawa et al., 2014; Pollak Dorocic et al., 2014; Sun et al., 2014; Weissbourd et al., 2014). The results have led to novel insights into the relationships between the organization and function of neural circuits throughout the nervous system; from muscles or peripheral sensory receptors to the brain; and in nearly every neural system, from vision to motor function and neuromodulatory systems.

The fast and extensive adoption of the approach can be attributed to its power and versatility even when needing to generate and use viral tools that have not traditionally been easily accessible to systems neuroscientists. This powerful reagent overcomes the most difficult challenges of precisely identifying presynaptic partners separated by distances ranging from micrometers to centimeters; it directly relates presynaptic neurons to the starter cell(s) — the initial rabies-infected cell(s) — via synaptic connections. This is possible because RV spreads selectively between synaptically connected neurons and then travels exclusively and efficiently in the retrograde direction (except for some sensory neurons, see below) to label synaptic inputs, regardless of distance (Ugolini, 1995, 2008; Kelly and Strick, 2000; Wickersham et al., 2007b; Callaway, 2008). EnvA-pseudotyped RVdG (EnvA + RVdG, see below) has the additional property of selectively infecting genetically defined cell types. Finally, because RV is a means of delivering genetic material and any gene of interest can be inserted into the viral genome, these approaches have access to the full range of genetic tools for monitoring or manipulating neuronal activity or gene expression. These systems, therefore, have the versatility to tap into existing mouse lines and other genetic approaches to label the inputs to specific cell types, and to incorporate not only existing technologies but also any other genetic tools that are developed in the future.

\section{Rabies virology and the power} of $G$-deletion

A key advance in rabies circuit tracing was the development of RVdG (Etessami et al., 2000) and the subsequent recognition that this could overcome circuit-tracing limitations inherent to the intact virus (Wickersham et al., 2007b). Despite the ability of intact RV to identify synapses and relate them to the starter cells, it spreads across multiple synaptic steps, creating potential confounds in the interpretation of results. G-deletion enables not only the spread of RV to be monosynaptically restricted (as detailed below), but also pseudotyping and the selective primary infection of genetically defined neurons. Together, these traits allow labeling of the direct monosynaptic inputs to genetically defined neurons.

Some basic knowledge of rabies virology and of viral pseudotyping is helpful in understanding the concepts that allow for monosynaptic tracing from selected cells and in guiding the design and interpreta- 

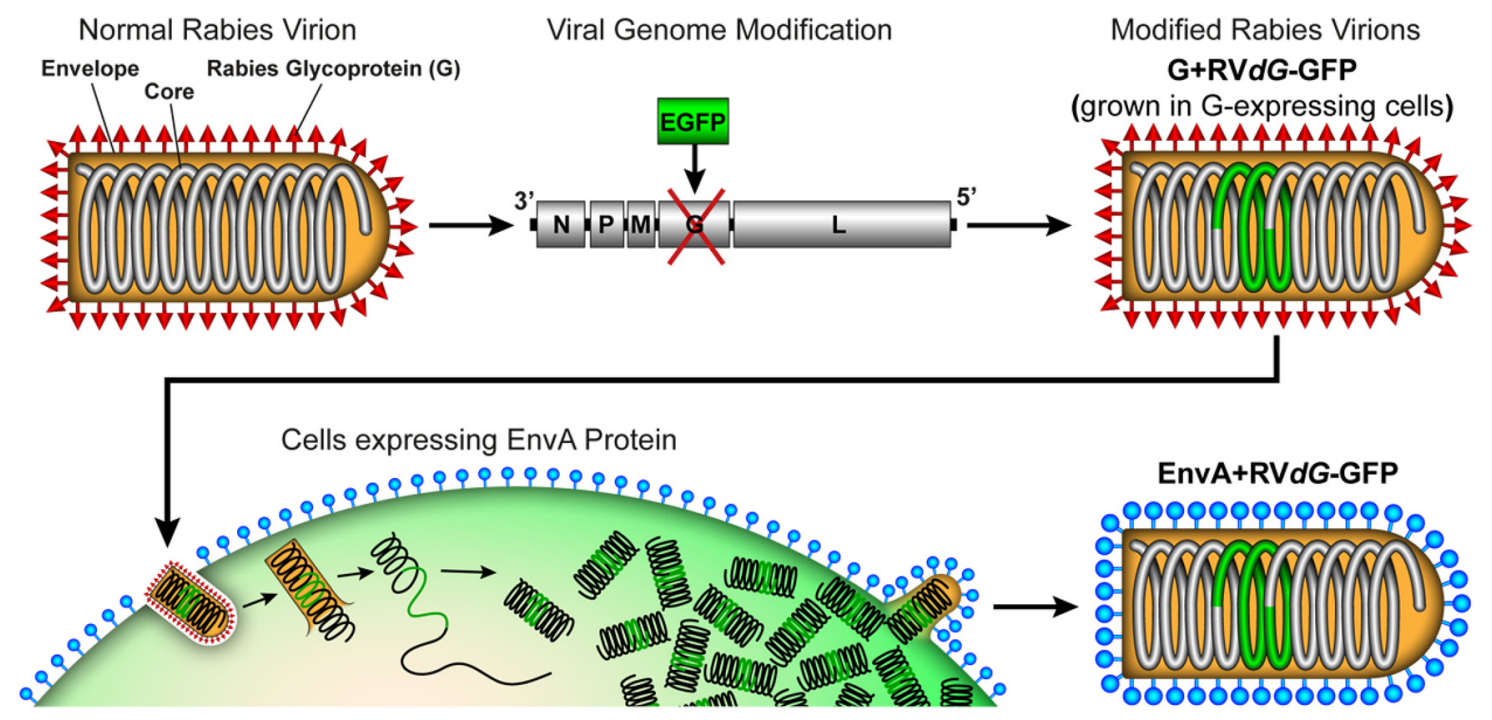

Figure 1. Glycoprotein deletion and EnvA pseudotyping of rabies virus. Normal rabies viral particles (top, left) are composed of a viral core surrounded by a host cell-derived membrane envelope in which the rabies glycoprotein (G; red spikes) is embedded. The core of the virus includes structural proteins and the negative strand RNA genome. The genome codes for five different proteins, including $\mathrm{G}$ (top, middle). The viral genome can be modified such that the coding sequence for $\mathrm{G}$ is deleted and can be replaced with the coding sequence for a transgene, such as GFP, which will be expressed in infected cells. G-deleted rabies virus particles (RVdG) are initially produced de novo from DNA and then can be propagated indefinitely (0sakada and Callaway, 2013). When propagated in cells that express $G$ (data not shown), RVdG particles will bud out from the host cells with $G$ on their envelope ( $G+R V d G$, top, right). To pseudotype RVdG, cells expressing EnvA (blue lollipops) are infected with $G+$ RVdG (bottom, left) and the particles that emerge will have EnvA on their envelope (bottom, right). These EnvA-pseudotyped particles are designated EnvA + RVdG.

tion of experiments that use these tools. $\mathrm{RV}$ is a negative strand RNA virus whose genome encodes for only five proteins (Fig. 1; Knipe and Howley, 2007). These include proteins for transcribing and replicating the genome and structural components. A key structural component is G. As illustrated in Figure 1, rabies $G$ is an envelope protein embedded in host-cell membrane after translation, which then interacts with the viral core to mediate budding of host cell-derived membraneenveloped viral particles out of the host cell. Wild-type RV particles display G on their surface (Fig. 1, top, left) allowing them to infect presynaptic nerve terminals via receptors for G. RV has broad tropism and can infect all neuronal types across all tested mammalian species. The development of methods for constructing genetically altered negative strand RNA viruses de novo from DNA (Schnell et al., 1994) has allowed the production of RVdG (Mebatsion et al., 1996), and this virus can then be propagated indefinitely using G-expressing cells for trans-complementation. Importantly, the release of viral particles is negligible in the absence of $G$ and $G$ is essential for the transneuronal transfer of RV, making RVdG unable to spread without trans-complementation (Etessami et al., 2000). If $\mathrm{G}$ is expressed in cells of interest as a transgene and these cells are infected with RVdG, then these cells can make infectious particles by transcomplementation (we refer to such particles as G + RVdG; Fig. 1, top, right), and these particles have the same wide tropism as wild-type RV. The absence of G from the viral genome also allows for pseudotyping - the provision of an alternative envelope protein that can interact with the $\mathrm{RV}$ core to mediate viral budding and production of viral particles with the foreign envelope protein instead of rabies $G$ (Fig. 1, bottom). Because it is the interaction between the envelope protein of the virus and cell-surface receptors in the recipient cell that dictates the ability of a virus to infect a particular cell, pseudotyping can alter the cell types that a virus is able to infect. Ideally, $\mathrm{RVd} G$ is pseudotyped in a way that allows it to selectively and efficiently infect cells of interest without any infection of other cells. For use in mammals, RVdG is typically pseudotyped with the envelope protein from avian ASLV type A (EnvA), which uses the TVA receptor for entry (we refer to such particles as EnvA + RVdG; Fig. 1, bottom). Because mammalian neurons do not express TVA, only cells engineered to express TVA can be infected by EnvA + RVdG (Young et al., 1993). EnvA + RVdG is produced by infecting cells that express EnvA with $\mathrm{G}+\mathrm{RVdG}$ and subsequently collecting and purifying the viral particles that emerge (Osakada and Callaway, 2013; Fig. 1, bottom). Purification is crucial for eliminating any $\mathrm{G}+\mathrm{RV} d G$ particles that might persist from the initial inoculation of the cultured cells. Properly produced and purified EnvA + RVdG is unable to infect normal mammalian neurons but will efficiently infect TVAexpressing neurons (see further below). Finally, it is important to note that any gene of interest can be inserted into the RV genome (e.g., GFP; Fig. 1) for marking or genetic manipulation of infected cells.

Basic strategies for circuit tracing with $G$-deleted rabies

The most basic approach for labeling direct inputs to specific cell types is exemplified in Figure 2. First, the initial RV infection is targeted to starter cells of interest by expressing TVA selectively in those cells. This allows selective infection of those cells with EnvA + RVdG. In this example the EnvA + RVdG has GFP inserted into the viral genome (EnvA + RVdG-GFP) so that any cell infected with RV will express and be labeled with GFP. In addition, the starter cells also express a unique marker gene, for example, an RFP (Miyamichi et al., 2011) or a TVAmCherry fusion protein (Watabe-Uchida et al., 2012), allowing them to be uniquely identified for subsequent analyses. Because RVdG is not able to spread between neurons in the absence of $\mathrm{G}, \mathrm{G}$ also needs to be expressed in the starter cells. While there are many possible ways to achieve $G$ expression it must not be from the RV genome. The $\mathrm{G}$ expressed in trans allows for trans-complementation and the production of $\mathrm{G}+\mathrm{RVd} G$ particles that can bud out from the starter cells. Importantly, these particles have rabies $G$ in their enve- 


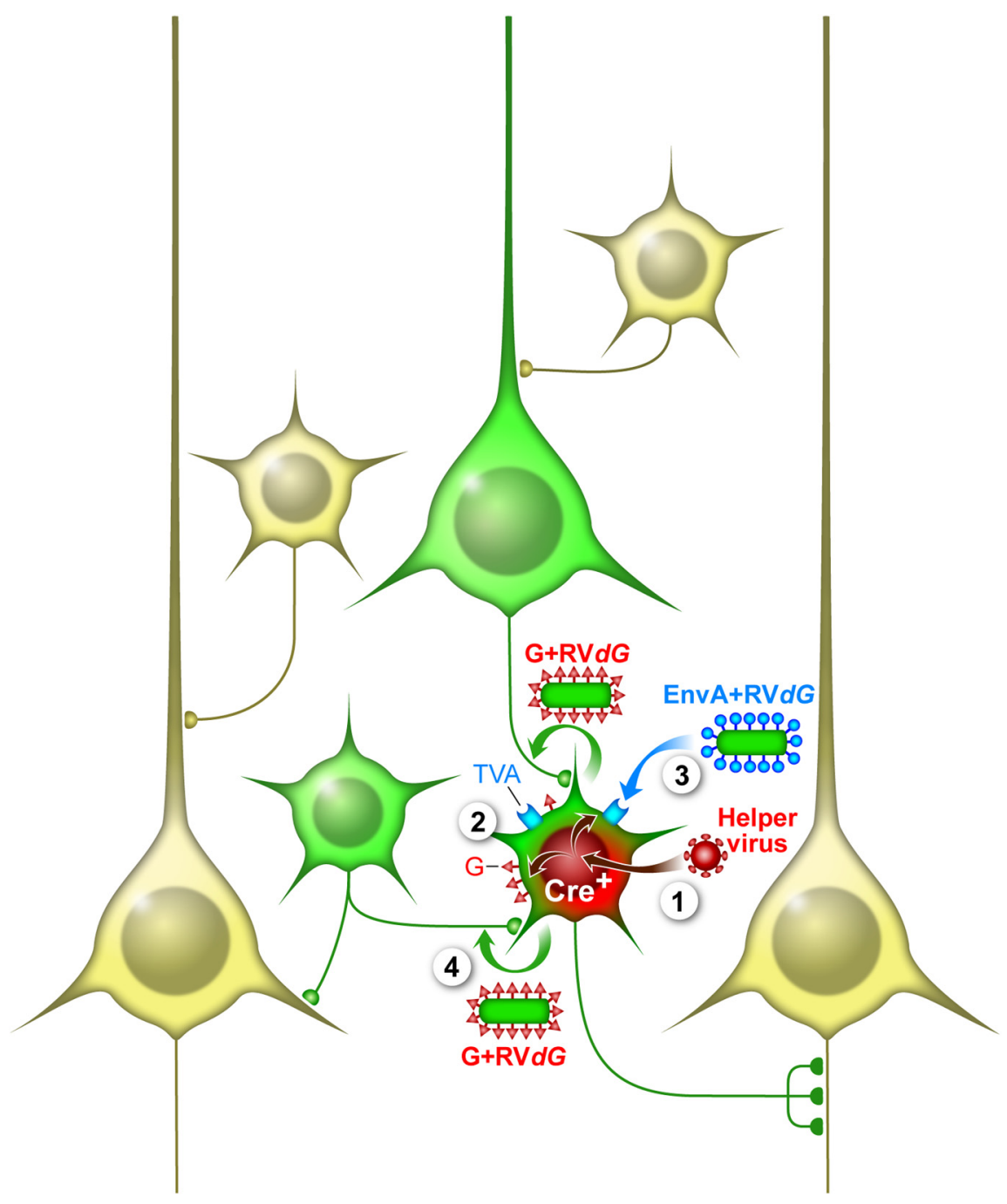

Figure 2. Monosynaptic rabies tracing of inputs to Cre-expressing starter cells. Monosynaptic tracing with G-deleted rabies (RVdG) involves expression of the EnvA receptor, TVA, and rabies glycoprotein (G) in starter cells. These cells are subsequently infected specifically with EnvA + RVdG, which is trans-complemented by $G$ to produce $G+R V d G$ that spreads trans-synaptically to neurons providing synaptic input to starter cells. The spread of RV $d G$ is monosynaptically restricted because the input cells lack $G$ and $G$ is required for trans-synaptic spread. In this example, the starter cells are selected on the basis of Cre expression in a mouse line expressing (re in a cell type of interest. In the first step (1) a helper virus that expresses TVA, G, and a marker gene (RFP) in a Cre-dependent manner is injected in the location of desired starter cells. This results in expression of TVA, G, and RFP only in the Cre + cells (green and red) (2). After a sufficient time for accumulation of TVA and G, EnvA + RVdG is injected in the location (3) and selectively infects the TVA + starter cells. In this example the EnvA + RVdG contains the coding sequence for GFP resulting in GFP expression in the starter cells. The RVdG replicates in the starter cells and trans-complementation with G results in the production of $G+R V d G$ that spreads trans-synaptically to input cells (4), which express GFP from the RV genome (green). The result is that starter cells are marked with both RFP and GFP while input cells express only GFP. Other neurons that do not express Cre and are not directly presynaptic to starter cells remain unlabeled (light yellow).

lope and thus have the normal infectious properties of the intact virus. They are taken up selectively at synaptic sites by the presynaptic terminals of neurons connected to the starter cells and then transported to the cell body where GFP is expressed to label these input cells. Despite the spread of the RVdG to cells providing direct input to the starter cells, the virus is unable to spread any further and is monosynaptically restricted. This is because the input cells do not express rabies $\mathrm{G}$ and cannot complement RVdG for fur- ther trans-synaptic spread. The result is that starter cells express both GFP and RFP while input cells throughout the brain express only GFP. The ability to distinguish starter cells and presynaptic inputs in the same sample also allows researchers to use a convergence index-the ratio between the number of presynaptic input cells (GFP only) over the number of starter cells (GFP and RFP double positive) - to approximately estimate the trans-synaptic efficiency (Miyamichi et al., 2011).
Tracing direct inputs to specific cell types using Cre lines

Building on the basic strategy above, we describe methods for labeling inputs to specific cell types by considering the case in which starter cells are accessed using cell type-specific Cre driver lines. This is the most widespread approach and this example illustrates mechanisms underlying trade-offs between selectivity and efficiency; similar considerations apply to other approaches.

Numerous mouse lines are available that express Cre recombinase selectively in cell types of interest. To label the direct monosynaptic inputs to Cre+ neurons, Cre-dependent expression of $\mathrm{G}$ and TVA first need to be generated in the desired starter cell population (Fig. 2). This has been done by either infecting neurons in the desired starter cell location with a Credependent helper virus (Figure 2; Wall et al., 2010; among many other publications cited previously), or by crossing the Cre driver line with a responder mouse line that has Cre-dependent expression of TVA and G (Li et al., 2013; Takatoh et al., 2013; Stanek et al., 2014; Bourane et al., 2015). Following adequate expression of the Cre-dependent gene products, EnvA $+\mathrm{RVd} G$ is injected which, as described above, can result in selective infection of starter cells. Following a survival time (typically 3-10 d) to allow for transsynaptic spread of RV and labeling of direct inputs, the results can be analyzed. It should be apparent that similar strategies can be used based on driver lines that express other recombinases or tTA in specific cell types (Weible et al., 2010; Miyamichi et al., 2011).

There are distinct advantages and disadvantages of using helper virus versus mouse lines (or combinations thereof) to achieve selective expression of TVA and G. The use of a mouse line obviates the need for helper virus injection, but for some purposes may not result in adequate restriction of $\mathrm{G}$ expression. For example, suppose one wishes to identify the locations of neurons providing input to layer 5 pyramidal neurons in the visual cortex by using TLX-Cre mice that express Cre only in layer 5 cells (Gerfen et al., 2013). Crossing these mice with a TVA $+\mathrm{G}$ responder line will result in expression in layer 5 throughout the cerebral cortex. When EnvA $+\mathrm{RV} d G$ is later injected into the visual cortex it will selectively infect layer 5 pyramids and trans-complementation by $\mathrm{G}$ will allow spread of $\mathrm{G}+\mathrm{RVd} G$ to input cells. However, many of these input neurons will be layer 5 cells in other cor- 
tical areas and they will also express G. This will result in further trans-complementation and spread of $\mathrm{G}+\mathrm{RVdG}$ across additional synaptic steps; RV spread will thus not be monosynaptically restricted. In contrast a helper virus injection can restrict expression of $\mathrm{G}$ and TVA to cells of a particular type and at a particular location, therefore, eliminating the possibility of $G$ expression and transsynaptic spread from neurons outside of the location of the helper virus injection. On the other hand, the use of a mouse line may reduce the likelihood of leak expression of TVA relative to the use of a helper virus (see below).

Ideally Cre-dependent gene expression should be absolutely restricted to Creexpressing neurons. However, under many conditions in both responder mouse lines and with helper viruses there is the potential for low levels of "leak" expression (Seidler et al., 2008; Wall et al., 2010; Miyamichi et al., 2013). These levels of leak might be undetectable by conventional methods such as fluorescent protein expression, but due to the extremely efficient interactions between wild-type TVA and EnvA-pseudotyped virus, otherwise undetectable levels of TVA can result in viral infection and expression of genes from the viral genome (Seidler et al., 2008). Such gene expression from EnvA + $\mathrm{RV} d G$ is particularly strong because infection with even a small number of RVdG particles can result in high levels of gene expression (Wickersham et al., 2007a; Wall et al., 2010). Neurons infected by EnvA + RVdG due to leak TVA expression can usually be identified in control experiments without a Cre source. Since in tracing experiments they cannot be distinguished from presynaptic partners of starter cells, this compromises data analysis at least for local tracing (usually long-range inputs are not compromised because leak expression of $\mathrm{G}$ is not strong enough for trans-complementation of $\mathrm{RVd} G$ ).

A strategy to minimize Cre-independent local background is to reduce binding affinity between TVA and EnvA. Thanks to extensive structure-function studies of EnvA-TVA binding, TVA mutants that differ in the degree of attenuation of their ability to mediate EnvA-coated viral entry have been described (Zingler et al., 1995; Rong et al., 1998). When replacing wildtype TVA with a mutant TVA with $10 \%$ efficiency for viral entry (TVA66T), it was found that Cre-independent background labeling was almost entirely eliminated in the olfactory bulb, motor cortex, dorsal raphe (Miyamichi et al., 2013; Weissbourd et al., 2014), and other areas we have examined (L. Luo, unpublished data). On the other hand, it appears that tracing efficiency for long-range input, as judged by convergence ratio, was also reduced despite the same level of $G$ expression (Miyamichi et al., 2013). In principle, TVA66T should only affect the efficiency of producing starter cells rather than trans-synaptic efficiency once starter cells are produced. That long-range input is affected by TVA66T suggests the efficiency is boosted by (1) higher numbers of EnvA $+\mathrm{RVd} G$ viral particles infecting the same starter cell and/or (2) more starter cells spreading $\mathrm{RVdG}$ to the same long-range input neuron.

Another possibility that might be preferred for some situations is a hybrid approach in which a mouse line that is less likely than a helper virus to have leak expression is used for expression of TVA only (Seidler et al., 2008) and a helper virus is used for expression of $\mathrm{G}$ (to maximize $G$ expression and trans-synaptic efficiency, see below). We have crossed the TVA-only line (Seidler et al., 2008) with several different Cre driver lines and have found no leak expression in the cerebral cortex. There is no infection in Cre-negative mice and EnvA + RVdG infection is restricted to the correct cell types in the absence of G (E.M.C., unpublished data).

In summary, Cre-dependent production of starter cells allows monosynaptic input to be identified to cell types that selectively express Cre recombinase. It is essential to perform control experiments in the absence of Cre recombinase to test background EnvA + RVdG infection due to leak TVA expression from the helper viruses or mouse lines. The efficiency of background labeling can vary by orders of magnitude depending on the efficiency of the reagents and brain areas. In all cases we have encountered, replacing TVA with TVA66T reduces background to nearly 0 , while supporting efficient local transsynaptic tracing. For long-range inputs, which are usually outside the background labeling, using wild-type TVA may improve trans-synaptic efficiency.

Tracing direct inputs to specific cells using other methods

Although Cre lines are the most common way to access specific cell types, rabiesmediated input tracing can also be performed by a variety of other approaches. We discuss a few such methods in this section.
Specific types of neurons can be accessed based on their axonal projection patterns. A salient example is motor neurons within a specific motor pool, which by definition all innervate the same muscle. Thus by injecting AAV that expresses $\mathrm{G}$ (an AAV serotype that efficiently infects young motor neurons from axon terminals) along with $\mathrm{G}+\mathrm{RVd} G$ into a specific muscle, functional RV can be reconstituted in motor neurons innervating that muscle and trans-synaptically spread to premotor neurons that are presynaptic to that motor pool (Stepien et al., 2010). Viruses that infect neurons via axonal projections, including AAV, canine adenovirus 2, and HSV, have also been used to initiate rabies tracing from CNS neurons with specific projection patterns (Yonehara et al., 2011; Yonehara et al., 2013; Pivetta et al., 2014; Schwarz et al., 2015).

Tracing input to a sparse population of starter cells or to single neurons can provide valuable insights into the circuit mechanisms by which individual neurons integrate information. This can be achieved by injecting a small amount of tamoxifen into transgenic mice expressing CreER (tamoxifen-activated Cre) and Cre-dependent tTA transgenes; tTA in turn controls the expression of G and TVA from an AAV helper virus (Miyamichi et al., 2011). This strategy has been used to reveal organization of the olfactory cortex regarding input from the olfactory bulb. The ultimate sparse labeling is to create a single starter cell. This has been achieved through delivery of plasmids expressing TVA and G by single-cell electroporation or during whole-cell recordings (Marshel et al., 2010; Rancz et al., 2011; Vélez-Fort et al., 2014). In the case of whole-cell recordings it has been possible to directly relate the visual response properties of single neurons to their inputs.

\section{Limitations and potential improvements} Incomplete labeling. An important limitation of monosynaptic tracing with $\mathrm{RVdG}$ is that under most conditions it only labels a fraction of inputs to starter cells. The limiting factors appear to include the following: levels of $\mathrm{G}$ expression in starter cells (see below), initial numbers of RVdG particles entering the starter cells (see above), and time available for transsynaptic spread before starter cells die (see below). Comparisons of results from studies quantifying inputs to singlestarter neurons provide some insight into the efficiency of spread and mechanisms that might be involved. Marshel et al. 
(2010) electroporated DNA into singlestarter pyramidal neurons in layer $2 / 3$ of mouse visual cortex and observed 14-97 input cells per starter (average of 49). The actual number of inputs per cell is unknown, but Golgi studies show that these cells have $\sim 1200$ dendritic spines each, placing a theoretical maximum on the number of excitatory inputs. But each input cell may make five synapses onto the starter cell (Feldmeyer et al., 2002, 2006), dropping the number of excitatory inputs to as low as $\sim 250$. A realistic estimate for this cell type might be $\sim 600$ inputs. Regardless, the observed number of inputs per starter must be far short of the total. Miyamichi et al. (2011) used a helper AAV with tTA driving a TRE promoter likely to result in higher levels of expression of both TVA and G than single-cell electroporation. They observed a much higher number of 250 inputs per mouse cortical neuron. Finally, Rancz et al. (2011) observed $\sim 500$ inputs per mouse layer 5 pyramidal neuron, possibly reflecting greater efficiency of transfection during whole-cell recording versus single-cell electroporation, or alternatively a larger number of inputs onto layer 5 neurons compared with layer $2 / 3$ neurons. One lesson from these observations is that the amount of $G$ expressed in starter cells should be maximized. Trans-synaptic spread might also be increased by using $G$ from different strains of RV that are likely to differ in their efficiency of packaging or uptake (Mori and Morimoto, 2014). We are therefore actively developing and testing $\mathrm{G}$ from various strains of RV and producing chimeric $G$ particles that are optimized both for packaging efficiency (interactions with the viral core and budding out from host cells) and uptake by presynaptic neurons (E.M.C., unpublished results).

Differential spread. If rabies does not label all of the inputs to each starter cell, then it naturally follows that the probability of labeling is likely to be different for different input cells. This could depend, for example, on the numbers of synaptic contacts, the subcellular locations of synaptic contacts, or receptors for $G$ that might differ on the axon terminals of different input cell types. This caveat should always be considered when interpreting results. For example, one might compare the fractional input onto starter cells for two different groups that have similar synapses. Published examples of such quantification include studies of inputs to dopamine receptor D1-expressing versus D2-expressing spiny projection neurons in the striatum (Wall et al., 2013), input to midbrain dopamine neurons in VTA versus SNc (Watabe-Uchida et al., 2012), input to dorsal raphe GABA versus serotonin neurons (Weissbourd et al., 2014), or inputs to serotonin neurons in dorsal versus median raphe (Ogawa et al., 2014; Pollak Dorocic et al., 2014). Ultimately labeling with RV can be used to indicate the presence of synaptic contacts between inputs and starter cells, but functional studies should complement those experiments when absolute measures of connection strength or other functional synaptic properties (e.g., neurotransmitters or receptors used, facilitation vs depression) are required. For example, ChR2 can be expressed in neurons that have been demonstrated to provide input using $\mathrm{RVdG}$ tracing and then whole-cell recordings made specifically from the recipient cell type of interest while photoactivating the input neurons to elicit and quantify functional responses (Petreanu et al., 2007; Weissbourd et al., 2014; Zhang et al., 2014).

Anterograde spread. Although RV spreads exclusively in the retrograde direction between connected neurons in the CNS, this is not the case for at least some peripheral sensory neurons. RV particles, including $\mathrm{RV} d G$, are able to directly infect peripheral sensory neurons in the DRG and olfactory sensory neurons, and can then be transported away from the cell body (Tsiang et al., 1989; Bauer et al., 2014) and spread transneuronally to neurons in the spinal cord (Zampieri et al., 2014). Because the anterograde transport of viral particles in sensory neurons is not restricted to rabies virus, but also occurs for the Bartha strain of PRV, which also transports exclusively in the retrograde direction in the CNS (Card et al., 1997), this trait is likely to be due to a peculiarity of sensory neurons rather than a feature of rabies virus. For example, DRG neurons are pseudo-unipolar cells that have a single process leaving the cell body that then bifurcates with one branch extending to the periphery and the other centrally. One would typically define the direction from the ends of one of these processes toward the cell body as retrograde and from the cell body out as anterograde. Perhaps in DRG neurons the molecular motors that typically mediate retrograde versus anterograde transport (Arnold, 2009) do not follow the rules expected from that definition. Motors that typically mediate transport in the retrograde direction might mediate transport from the cell body toward the CNS in DRG neurons. This ca- veat should be carefully considered when designing experiments or evaluating results in which sensory neurons might both be infected with RVdG and also express $G$ for possible trans-complementation.

Neuronal death due to long-term $R V$ infection. Relative to other neurotropic viruses that have been used for transsynaptic tracing, rabies has an important advantage that neurons survive much longer following infection. This allows for a time window during which functional studies may be conducted on neurons that have been identified based on their connectivity (e.g., see below). Nevertheless, $\mathrm{RV} d G$ infection invariably kills neurons. Studies of the time course over which neurons die find no reduction in numbers of cells until after $14 \mathrm{~d}$ (Wickersham et al., 2007a). Structural integrity of neurons and the trans-synaptic efficiency do not differ detectably when examined $4 \mathrm{~d}$ or $8 \mathrm{~d}$ after rabies infection (Miyamichi et al., 2013). It is likely, however, that cell health is affected before death. Whole-cell recordings in vitro and measurements of visual responses in vivo find no detectable effects on viability before $12 \mathrm{~d}$ (Wickersham et al., 2007a; Osakada et al., 2011), but an inability to make whole-cell recording from cells at $12 \mathrm{~d}$ after infection strongly suggests that viability is affected by that time (Osakada et al., 2011). Overall, these observations strongly suggest that cells are viable for at least 1 week after infection; therefore, it is advisable to conduct studies within this time frame.

\section{Modifying the rabies genome to interrogate neural circuit function}

Because it is possible to insert almost any gene of interest into the rabies genome and there is an $\sim 4-10 \mathrm{~d}$ period after RVdG infection when neurons are viable but transgene is highly expressed, there is an opportunity to use genetic approaches to directly link connectivity to circuit function. For example, expression of optogenetic or chemogenetic tools from the rabies genome (Osakada et al., 2011) allows photo or chemical activation or inhibition of neurons defined by their inputs to particular starter cells so that their importance to in vivo function can be assayed. Genetically encoded activity indicators expressed from the RVdG genome have been used to directly relate visual responses to connectivity in the mouse visual system (Osakada et al., 2011; Yonehara et al., 2013), and the expression of Cre recombinase can mediate genetic alterations of connectionally defined neurons in susceptible mouse lines. The use of 
RVdG is likely to continue to evolve as new genetic tools are developed and incorporated into the RVdG genome. Developing $\mathrm{RVd} G$ variants that prolong the health and survival of infected neurons will further improve the utility of this powerful tool.

\section{References}

Arenkiel BR, Hasegawa H, Yi JJ, Larsen RS, Wallace ML, Philpot BD, Wang F, Ehlers MD (2011) Activity-induced remodeling of olfactory bulb microcircuits revealed by monosynaptic tracing. PLoS One 6:e29423. CrossRef Medline

Arnold DB (2009) Actin and microtubule-based cytoskeletal cues direct polarized targeting of proteins in neurons. Sci Signal 2:pe49. CrossRef Medline

Bauer A, Nolden T, Schröter J, Römer-Oberdörfer A, Gluska S, Perlson E, Finke S (2014) Anterograde glycoprotein-dependent transport of newly generated rabies virus in dorsal root ganglion neurons. J Virol 88:14172-14183. CrossRef Medline

Bourane S, Grossmann KS, Britz O, Dalet A, Del Barrio MG, Stam FJ, Garcia-Campmany L, Koch S, Goulding M (2015) Identification of a spinal circuit for light touch and fine motor control. Cell 160:503-515. CrossRef Medline

Callaway EM (2008) Transneuronal circuit tracing with neurotropic viruses. Curr Opin Neurobiol 18:617-623. CrossRef Medline

Card JP, Enquist LW, Miller AD, Yates BJ (1997) Differential tropism of pseudorabies virus for sensory neurons in the cat. J Neurovirol 3: 49-61. CrossRef Medline

Choi J, Callaway EM (2011) Monosynaptic inputs to ErbB4-expressing inhibitory neurons in mouse primary somatosensory cortex. J Comp Neurol 519:3402-3414. CrossRef Medline

Cruz-Martín A, El-Danaf RN, Osakada F, Sriram B, Dhande OS, Nguyen PL, Callaway EM, Ghosh A, Huberman AD (2014) A dedicated circuit links direction-selective retinal ganglion cells to the primary visual cortex. Nature 507:358-361. CrossRef Medline

Deshpande A, Bergami M, Ghanem A, Conzelmann KK, Lepier A, Götz M, Berninger B (2013) Retrograde monosynaptic tracing reveals the temporal evolution of inputs onto new neurons in the adult dentate gyrus and olfactory bulb. Proc Natl Acad Sci U S A 110: E1152-E1161. CrossRef Medline

Etessami R, Conzelmann KK, Fadai-Ghotbi B, Natelson B, Tsiang H, Ceccaldi PE (2000) Spread and pathogenic characteristics of a G-deficient rabies virus recombinant: an in vitro and in vivo study. J Gen Virol 81:21472153. Medline

Feldmeyer D, Lübke J, Silver RA, Sakmann B (2002) Synaptic connections between layer 4 spiny neurone-layer $2 / 3$ pyramidal cell pairs in juvenile rat barrel cortex: physiology and anatomy of interlaminar signalling within a cortical column. J Physiol 538:803-822. CrossRef Medline

Feldmeyer D, Lübke J, Sakmann B (2006) Efficacy and connectivity of intracolumnar pairs of layer $2 / 3$ pyramidal cells in the barrel cortex of juvenile rats. J Physiol 575:583-602. CrossRef Medline

Fu Y, Tucciarone JM, Espinosa JS, Sheng N, Darcy DP, Nicoll RA, Huang ZJ, Stryker MP (2014) A cortical circuit for gain control by behavioral state. Cell 156:1139-1152. CrossRef Medline

Garcia I, Quast KB, Huang L, Herman AM, Selever J, Deussing JM, Justice NJ, Arenkiel BR (2014) Local CRH signaling promotes synaptogenesis and circuit integration of adult-born neurons. Dev Cell 30:645-659. CrossRef Medline

Gerfen CR, Paletzki R, Heintz N (2013) GENSAT BAC cre-recombinase driver lines to study the functional organization of cerebral cortical and basal ganglia circuits. Neuron 80:1368-1383. CrossRef Medline

Haubensak W, Kunwar PS, Cai H, Ciocchi S, Wall NR, Ponnusamy R, Biag J, Dong HW, Deisseroth K, Callaway EM, Fanselow MS, Lüthi A, Anderson DJ (2010) Genetic dissection of an amygdala microcircuit that gates conditioned fear. Nature 468:270-276. CrossRef Medline

Kelly RM, Strick PL (2000) Rabies as a transneuronal tracer of circuits in the central nervous system. J Neurosci Methods 103:63-71. CrossRef Medline

Knipe DM, Howley PM (2007) Fields virology, ed 5. Philadelphia: Lippincott Williams \& Wilkins.

Kohara K, Pignatelli M, Rivest AJ, Jung HY, Kitamura T, Suh J, Frank D, Kajikawa K, Mise N, Obata Y, Wickersham IR, Tonegawa S (2014) Cell type-specific genetic and optogenetic tools reveal hippocampal CA2 circuits. Nat Neurosci 17:269-279. CrossRef Medline

Levine AJ, Hinckley CA, Hilde KL, Driscoll SP, Poon TH, Montgomery JM, Pfaff SL (2014) Identification of a cellular node for motor control pathways. Nat Neurosci 17:586-593. CrossRef Medline

Li Y, Stam FJ, Aimone JB, Goulding M, Callaway EM, Gage FH (2013) Molecular layer perforant path-associated cells contribute to feed-forward inhibition in the adult dentate gyrus. Proc Natl Acad Sci U S A 110:91069111. CrossRef Medline

Marshel JH, Mori T, Nielsen KJ, Callaway EM (2010) Targeting single neuronal networks for gene expression and cell labeling in vivo. Neuron 67:562-574. CrossRef Medline

Mebatsion T, Konig M, Conzelmann KK (1996) Budding of rabies virus particles in the absence of the spike glycoprotein. Cell 84:941951. CrossRef Medline

Miyamichi K, Amat F, Moussavi F, Wang C, Wickersham I, Wall NR, Taniguchi H, Tasic B, Huang ZJ, He Z, Callaway EM, Horowitz MA, Luo L (2011) Cortical representations of olfactory input by trans-synaptic tracing. Nature 472:191-196. CrossRef Medline

Miyamichi K, Shlomai-Fuchs Y, Shu M, Weissbourd BC, Luo L, Mizrahi A (2013) Dissecting local circuits: parvalbumin interneurons underlie broad feedback control of olfactory bulb output. Neuron 80:1232-1245. CrossRef Medline

Mori T, Morimoto K (2014) Rabies virus glycoprotein variants display different patterns in rabies monosynaptic tracing. Front Neuroanat 7:47. CrossRef Medline
Nakashiba T, Cushman JD, Pelkey KA, Renaudineau S, Buhl DL, McHugh TJ, Rodriguez Barrera V, Chittajallu R, Iwamoto KS, McBain CJ, Fanselow MS, Tonegawa S (2012) Young dentate granule cells mediate pattern separation, whereas old granule cells facilitate pattern completion. Cell 149:188201. CrossRef Medline

Ni Y, Nawabi H, Liu X, Yang L, Miyamichi K, Tedeschi A, Xu B, Wall NR, Callaway EM, He Z (2014) Characterization of long descending premotor propriospinal neurons in the spinal cord. J Neurosci 34:9404-9417. CrossRef Medline

Ogawa SK, Cohen JY, Hwang D, Uchida N, Watabe-Uchida M (2014) Organization of monosynaptic inputs to the serotonin and dopamine neuromodulatory systems. Cell Rep 8:1105-1118. CrossRef Medline

Osakada F, Callaway EM (2013) Design and generation of recombinant rabies virus vectors. Nat Protoc 8:1583-1601. CrossRef Medline

Osakada F, Mori T, Cetin AH, Marshel JH, Virgen B, Callaway EM (2011) New rabies virus variants for monitoring and manipulating activity and gene expression in defined neural circuits. Neuron 71:617-631. CrossRef Medline

Petreanu L, Huber D, Sobczyk A, Svoboda K (2007) Channelrhodopsin-2-assisted circuit mapping of long-range callosal projections. Nat Neurosci 10:663-668. CrossRef Medline

Pivetta C, Esposito MS, Sigrist M, Arber S (2014) Motor-circuit communication matrix from spinal cord to brainstem neurons revealed by developmental origin. Cell 156:537-548. CrossRef Medline

Pollak Dorocic I, Fürth D, Xuan Y, Johansson Y, Pozzi L, Silberberg G, Carlén M, Meletis K (2014) A whole-brain atlas of inputs to serotonergic neurons of the dorsal and median raphe nuclei. Neuron 83:663-678. CrossRef Medline

Rancz EA, Franks KM, Schwarz MK, Pichler B, Schaefer AT, Margrie TW (2011) Transfection via whole-cell recording in vivo: bridging single-cell physiology, genetics and connectomics. Nat Neurosci 14:527-532. CrossRef Medline

Rong L, Gendron K, Strohl B, Shenoy R, WoolLewis RJ, Bates P (1998) Characterization of determinants for envelope binding and infection in TVA, the subgroup A avian sarcoma and leukosis virus receptor. J Virol 72:45524559. Medline

Schnell MJ, Mebatsion T, Conzelmann KK (1994) Infectious rabies viruses from cloned cDNA. EMBO J 13:4195-4203. Medline

Schwarz LA, Miyamichi K, Gao XJ, Beier KT, Weissbourd B, DeLoach KE, Ren J, Ibanes S, Malenka RC, Kremer EJ, Luo L (2015) Viralgenetic tracing of the input-output organization of a central norepinephrine circuit. Nature, in press.

Seidler B, Schmidt A, Mayr U, Nakhai H, Schmid RM, Schneider G, Saur D (2008) A CreloxP-based mouse model for conditional somatic gene expression and knockdown in vivo by using avian retroviral vectors. Proc Natl Acad Sci U S A 105:10137-10142. CrossRef Medline 
Sreenivasan V, Karmakar K, Rijli FM, Petersen CC (2015) Parallel pathways from motor and somatosensory cortex for controlling whisker movements in mice. Eur J Neurosci 41:354367. CrossRef Medline

Stanek E 4th, Cheng S, Takatoh J, Han BX, Wang F (2014) Monosynaptic premotor circuit tracing reveals neural substrates for oromotor coordination. eLife 3:e02511. CrossRef Medline

Stepien AE, Tripodi M, Arber S (2010) Monosynaptic rabies virus reveals premotor network organization and synaptic specificity of cholinergic partition cells. Neuron 68:456472. CrossRef Medline

Sun Y, Nguyen AQ, Nguyen JP, Le L, Saur D, Choi J, Callaway EM, Xu X (2014) Cell-type-specific circuit connectivity of hippocampal CA1 revealed through Cre-dependent rabies tracing. Cell Rep 7:269-280. CrossRef Medline

Takatoh J, Nelson A, Zhou X, Bolton MM, Ehlers MD, Arenkiel BR, Mooney R, Wang F (2013) New modules are added to vibrissal premotor circuitry with the emergence of exploratory whisking. Neuron 77:346-360. CrossRef Medline

Tsiang H, Lycke E, Ceccaldi PE, Ermine A, Hirardot X (1989) The anterograde transport of rabies virus in rat sensory dorsal root ganglia neurons. J Gen Virol 70:2075-2085. CrossRef Medline

Ugolini G (1995) Specificity of rabies virus as a transneuronal tracer of motor networks: transfer from hypoglossal motoneurons to connected second-order and higher order central nervous system cell groups. J Comp Neurol 356:457-480. CrossRef Medline

Ugolini G (2008) Use of rabies virus as a transneuronal tracer of neuronal connections: implications for the understanding of rabies pathogenesis. Dev Biol (Basel) 131:493-506. Medline

Vélez-Fort M, Rousseau CV, Niedworok CJ, Wickersham IR, Rancz EA, Brown AP, Strom M, Margrie TW (2014) The stimulus selectivity and connectivity of layer six principal cells reveals cortical microcircuits underlying visual processing. Neuron 83:1431-1443. CrossRef Medline

Vivar C, Potter MC, Choi J, Lee JY, Stringer TP, Callaway EM, Gage FH, Suh H, van Praag H (2012) Monosynaptic inputs to new neurons in the dentate gyrus. Nat Commun 3:1107. CrossRef Medline

Wall NR, Wickersham IR, Cetin A, De La Parra M, Callaway EM (2010) Monosynaptic circuit tracing in vivo through Cre-dependent targeting and complementation of modified rabies virus. Proc Natl Acad Sci U S A 107:2184821853. CrossRef Medline

Wall NR, De La Parra M, Callaway EM, Kreitzer AC (2013) Differential innervation of direct- and indirect-pathway striatal projection neurons. Neuron 79:347-360. CrossRef Medline

Watabe-Uchida M, Zhu L, Ogawa SK, Vamanrao A, Uchida N (2012) Whole-brain mapping of direct inputs to midbrain dopamine neurons. Neuron 74:858-873. CrossRef Medline

Weible AP, Schwarcz L, Wickersham IR, Deblander L, Wu H, Callaway EM, Seung HS, Kentros CG (2010) Transgenic targeting of recombinant rabies virus reveals monosynaptic connectivity of specific neurons. J Neurosci 30:16509-16513. CrossRef Medline

Weissbourd B, Ren J, DeLoach KE, Guenthner CJ, Miyamichi K, Luo L (2014) Presynaptic partners of dorsal raphe serotonergic and GABAergic neurons. Neuron 83:645-662. CrossRef Medline

Wickersham IR, Finke S, Conzelmann KK, Calla- way EM (2007a) Retrograde neuronal tracing with a deletion-mutant rabies virus. Nat Methods 4:47-49. CrossRef Medline

Wickersham IR, Lyon DC, Barnard RJ, Mori T, Finke S, Conzelmann KK, Young JA, Callaway EM (2007b) Monosynaptic restriction of transsynaptic tracing from single, genetically targeted neurons. Neuron 53:639-647. CrossRef Medline

Yonehara K, Balint K, Noda M, Nagel G, Bamberg E, Roska B (2011) Spatially asymmetric reorganization of inhibition establishes a motionsensitive circuit. Nature 469:407-410. CrossRef Medline

Yonehara K, Farrow K, Ghanem A, Hillier D, Balint K, Teixeira M, Jüttner J, Noda M, Neve RL, Conzelmann KK, Roska B (2013) The first stage of cardinal direction selectivity is localized to the dendrites of retinal ganglion cells. Neuron 79: 1078-1085. CrossRef Medline

Young JA, Bates P, Varmus HE (1993) Isolation of a chicken gene that confers susceptibility to infection by subgroup A avian leukosis and sarcoma viruses. J Virol 67:1811-1816. Medline

Zampieri N, Jessell TM, Murray AJ (2014) Mapping sensory circuits by anterograde transsynaptic transfer of recombinant rabies virus. Neuron 81:766-778. CrossRef Medline

Zhang S, Xu M, Kamigaki T, Hoang Do JP, Chang WC, Jenvay S, Miyamichi K, Luo L, Dan Y (2014) Selective attention. Long-range and local circuits for top-down modulation of visual cortex processing. Science 345:660-665. CrossRef Medline

Zingler K, Bélanger C, Peters R, Agard E, Young JA (1995) Identification and characterization of the viral interaction determinant of the subgroup A avian leukosis virus receptor. J Virol 69:4261-4266. Medline 